\author{
Information \\ for Authors
}

The purpose of the Canadian Journal of Philosophy is the publication in Canada of philosophical work of high quality, in English or French, and in any field of philosophy. All submissions are given blind editorial review; those of departmental colleagues are externally refereed.

Manuscripts should be sent in triplicate to: Executive Secretary, Canadian Journal of Philosophy, Department of Philosophy, University of Lethbridge, Lethbridge, Alberta, Canada T1K 3M4. It is preferred that manuscripts be typed double-spaced, including quotes and footnotes. In general, the Canadian Journal of Philosophy follows The University of Chicago Manual of Style. Footnotes should be numbered consecutively and assembled on separate pages at the end of the manuscript. Manuscripts will not be returned unless return postage is prepaid by cheque, money-order, reply coupons, or Canadian stamps.

Authors will receive, without charge, 25 copies of their articles. Additional offprints may be ordered when the proofs are returned to the publisher.

The articles in C.J.P. are indexed in The Philosophers' Index, Bowling Green, Ohio, U.S.A., in the Reportoire bibliographique de la philosophie, Louvain, Belgium, and in the Canadian Periodical Index.

All enquiries of an editorial nature should be directed to the Executive Secretary at the above address.

The Canadian Journal of Philosophy a pour objet la publication canadienne, en langues anglaise ou française, d'études philosophiques de haut niveau, quel que soit le domaine philosophique auxquelles elles appartiennent. Les communications sont évaluées dans l'anonymat de leurs auteurs; celles que soumettent les collègues départementaux sont référées à un comité de lecture extérieur.

Les manuscrits, en triple exemplaire, doivent être adressés à La Secrétaire de Rédaction. Canadian Journal of Philosophy, University of Lethbridge, Lethbridge, Alberta, Canada T1K 3M4. Soumettre de préférence des manuscrits (citations et notes comprises) dactylographiés à double interligne, en prenant pour guide, dans la mesure du possible, The University of Chicago Manual of Style. Les notes doivent suivre la numérotation continue et figurer sur des feuilles indépendantes en annexe au manuscrit. Les textes non insérés ne sont rendus qu'en cas de prépaiement des frais de poste par chèque, mandat, coupons-réponse ou timbres canadiens.

Les auteurs recoivent gratuitement 25 tirés-à part de leur article. Ils sont priés, s'ils désirent en obtenir un plus grand nombre à titre onéreux, en informer l'imprimeur lors du renvoi des épreuves.

Les articles du C.J.P. sont catalogués dans The Philosopher's Index, Bowling Green, Ohio, E.-U., dans le Répertoire bibliographique de la philosophie, Louvain, Belgique, et dans l'Index de Périodiques Canadiens. 
Subscription Information
The Canadian Journal of Philosophy is published by the University of Calgary Press.

The Canadian Journal of Philosophy is published quarterly, in March, June, September and December. In addition to these regular issues, the C.J.P. publishes annually a supplementary volume of original papers on a selected theme of contemporary philosophical interest. This supplementary volume is free to individual and student subscribers to the journal in that year. Supplementary volumes may also be purchased separately.

Correspondence regarding subscriptions, renewals, single issues and supplementary volume orders should be addressed to Canadian Journal of Philosophy c/o The University of Calgary Press, University of Calgary, Calgary, Alberta, Canada T2N 1N4.

A subscription for the 1992 volume of four issues is:

$\begin{array}{lrr} & \text { Canada } & \text { Outside Canada } \\ \text { Institutions } & \mathrm{Cdn} . \$ 40.00 & \mathrm{US} \$ 40.00 \\ \text { Individuals } & 25.00 & 25.00 \\ \text { Students } & 15.00 & 15.00 \\ \text { Single issues } & 9.00 & 9.00\end{array}$

A joint subscription to Canadian Journal of Philosophy and the Australasian Journal of Philosophy is available to individuals at $\$ 40$ and to students at $\$ 25$. Outside Canada price is in US dollars. Canadian residents please add $7 \%$ GST.
The University of Calgary Press,

The University of Calgary, CALGARY, Alberta, Canada T2N 1N4
1992 Subscription $\square \quad$ Individual $\square$ 1992 Joint Subscription $\square \quad$ Student $\square$

Back Issue $\square$ No.

Please send me information on C.J.P. Supplementary Volumes $\square$

Name

Address

City

Country Postal Code

Visa $\square \quad$ Mastercard $\square \quad$ No.

Expiry Date Signature

Cheques should be made payable to The University of Calgary Press. 
Abonnements The Canadian Journal of Philosophy est publié par The University of Calgary Press.

The Canadian Journal of Philosophy est une publication trimestrielle paraissant en mars, juin, septembre et octobre. Outre ses quatre fascicules réguliers, il publie, annuellement, un supplément thématique d'articles inédits consacrés à des sujets d'actualité philosophique. Le supplément est offert gratuitement à tout abonné - particulier ou étudiant - de l'année courante. Les suppléments sont également disponibles à titre onéreux.

Toute correspondance concernant l'administration (abonnements, renouvellements, commandes de numéros et de suppléments) doit être adressée à The Canadian Journal of Philosophy, c/o The University of Calgary Press, The University of Calgary, Calgary, Alberta, Canada T2N 1N4.

Tarifs d'abonnement au volume 1992 (4 fascicules):

$\begin{array}{lrr} & \text { Canada } & \text { Hors-Canada } \\ \text { Institutions } & \text { Cdn. } \$ 40.00 & \text { US } \$ 40.00 \\ \text { Individus } & 25.00 & 25.00 \\ \text { Etudiants } & 15.00 & 15.00 \\ \text { Numéro simple } & 9.00 & 9.00\end{array}$

Tout individu ou étudiant peut souscrire, à raison de $\$ 40$ et $\$ 25$ respectivement, un double abonnement au Canadian Journal of Philosophy et à l'Australasian Journal of Philosophy. Règlement en dollars US pour tous ceux qui résident en dehors du Canada. Les résidents du Canada doivent payé la TPS.

\section{DCanadian

The University of Calgary Press, The University of Calgary, CALGARY, Alberta, Canada T2N 1N4

\begin{tabular}{rr} 
Abonnement $1992 \square$ & Individu $\square$ \\
Double Abonnement 1992 $\square$ & Etudiant $\square$ \\
Numéros disponsibles $\square$ No. & \\
\hline
\end{tabular}

Abonnement $1992 \square \quad$ Individu $\square$ Numéros disponsibles $\square$ No.

Veuillez me faire parvenir tous les renseignements concernant les suppléments du C.J.P.

Nom

Adresse

Ville

Pays Code Postal

Visa $\square \quad$ Mastercard $\square \quad$ No.

Date d'expiration Signature

Libeller tout chèque à l'ordre de The University of Calgary Press. 


\author{
Other \\ Business \\ Information
}

Automatic
Permission
to Reproduce

Back Issues

Services
administratifs
— détails
supplémen-
taires

Reproduction affranchie d'agrément préalable

\section{Volumes antérieurs}

All business correspondence, should be addressed to Canadian Journal of Philosophy, University of Calgary Press, Calgary, Alberta T2N 1N4. This includes enquiries concerning advertising and promotion, exchanges, and reprinting. The copyright for all materials appearing in the regular issues and in the supplements of this journal is held by the Canadian Journal of Philosophy, and consent for any reproduction or reprinting must be obtained with the following exception.

Permission to reproduce parts of individual numbers of Canadian Journal of Philosophy by photocopy, xerox, offset, etc., for scholarly purposes (but not for republishing by printing nor for sale to the public) is automatically granted without prior permission being secured at the following rates: first 5 copies, no charge; 4 cents for each copy in excess of five of each page of C.J.P.

Remuneration is to be paid to the Canadian Journal of Philosophy, stating title and author of the article and number of copies. Proceeds above $\$ 10.00$ from any one article will be shared with the author. This announcement applies retroactively to volume I, number 1 .

Canadian Joumal of Philosophy is indexed in Canadian Magazine Index by Micromedia Limited. Back volumes are available in microform from Micromedia Limited, 158 Pearl St., Toronto M5H 1L3. 416-593-5211.

Toute correspondance administrative, à l'exception de celle qui concerne les abonnements, renouvellements et commandes de numéros et de suppléments, doit être adressée aux Canadian Journal of Philosophy, University of Calgary Press, Calgary, Alberta T2N 1N4. Ecrire à l'adresse ci-dessus pour tous renseignements relatifs à la publicité et à la promotion, ainsi qu'aux échanges et aux réimpressions. Le copyright des articles afférents aux fascicules et suppléments est propriété du Canadian Journal of Philosophy. Leur reproduction ou réimpression en tout ou partie ne peut être faite sans l'agrément préalable de le Directeur de la Publication, sauf dans le cas suivant.

Est affranchie d'agrément préalable la reproduction partielle des numéros du Canadian Journal of Philosophy par procédé technique de photocopie, xerox, offset, etc., lorsqu'elle vise exclusivement à des fins ou à des recherches académiques. Est interdite toute réimpression ayant pour objet la vente au public. Conditions tarifaires de reproduction: $0-5$ copies, accordé à titre gracieux; 6 copies ou en plus, 4 cents pour chaque copie de chaque page du C.J.P.

Effectuer tout règlement à l'ordre du Canadian Journal of Philosophy. Avoir soin d'indiquer le nom de l'auteur et le titre de l'article à reproduire d'une part, et le nombre de copies requises, de l'autre. Les apports provenant d'un article sont partagés à égalité avec son auteur pour la part numéraire dépassant $\$ 10.00$ (règlement rétroactif au volume I, No. 1).

Canadian Journal of Philosophy est répertoirié par Micromedia ltée dans le Canadian Magazine Index et les volumes antérieurs sont disponibles en microforme chez Micromedia ltée, 158 Pearl St., Toronto M5H 1L3, 416-593-5211. 


\section{THE CLASSICAL WORLD}

Since 1907 THE CLASSICAL WORLD has provided a combination of services and features which make the journal an indispensable instrument for teaching and research in the Classics. It is published six times yearly $\rightarrow$ from September to July.

\section{Articles}

Volume 86, in addition to its regular features such as Scholia and Paedagogus, will carry the following articles of scholarly and general interest:

"A Gorgonic Archer: Danger of Sight in Euripides' Heracles," "The Attitude of Agamemnon," "The Resurrection of a Latin Classics: the Confessions of St. Augustine," "Latin Definiteness and English Articles," and "Sallust's Jugurtha: Rebel or Freedom Fighter?"

\section{Surveys}

$C W$ will offer as well a full survey of currently available audio-visual material and an update of its bibliography of annotated textbooks. Still available is its recently published Directory of College and University Classicists in the United States and Canada (\$20.00) and Books for Teaching the Classics in English (\$5.00).

\section{Reviews}

THE CLASSICAL WORLD specializes in brief and expert reviews of new books in all areas of classical antiquity. Volume 86 will feature approximately 200 such reviews.

\section{Books Received}

The journal offers extensive and immediate listings of all books received from publishers around the world with complete bibliographical information.

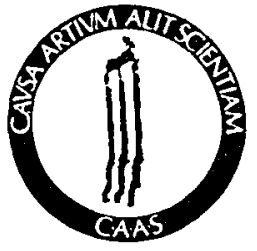

For subscription information, write:

THE CLASSICAL WORLD

Department of Classics

Duquesne University

Pittsburgh, PA 15282-1704 


\section{GNOSIS \\ A Journal of Philosophic Interest}

Gnosis is an annual journal of philosophy published under the auspices of the Department of Philosophy of Concordia University. Founded in 1972 for the purpose of promoting philosophical discussion on a wide variety of subjects, Gnosis is interested in publishing research by graduate students as well as professional philosophers and scholars. Undergraduate submissions of exceptional merit are also accepted.

\section{Recent Articles}

Christopher McNicolls / Ontological Freedom as the Essence of Dasein: Heidegger's Overcoming of Objectivism and Subjectivism

Joseph Wayne Smith / Logic, Contradiction, and Quantum Theory

James P. Danaher / Did Locke Believe that Real Essences Would Someday Be Knowable?

Pierre Boulos / The Relevance of Gödel's Theorem to Husserl's Formal and Transcendental Logic

David R. Lea / A Comparison of the Values which Animate Libertarian and Customary Melanesian Forms of Ownership and their Environmental Implications

Joseba I. Esteban / Habermas on Weber: Rationality, Rationalization, and the Diagnosis of the Times

Gerry Callaghan / Knowledge, Skepticism, and Public Assertability

Annual (1 issue) subscription rates: $\$ 5$ for institutions, $\$ 3$ for individuals, and $\$ 2$ for students.

All manuscripts, subscriptions, and other correspondence may be sent to the editors at

\section{GNOSIS}

Department of Philosophy

Concordia University

1455 de Maisonneuve Blvd. West

Montreal, Quebec

H3G 1M8 


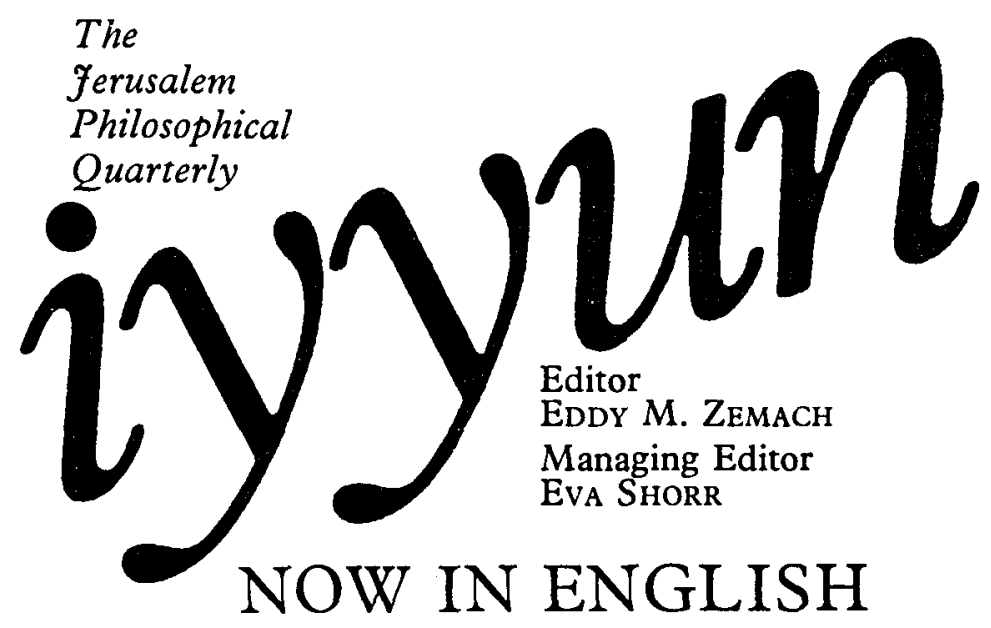

Published in Hebrew since 1945 at the Hebrew University of Jerusalem, as of vol. 39 (1990) Iyyun appears four times a year: January and July in English; April and October in Hebrew. The English issues include summaries of the articles in the Hebrew issues.

Iyyun accepts long essays, articles, and critical studies irrespective of philosophical school or method of inquiry.

Recent articles:

J. MARGOLIS: The Defeat of the Computational Model of the Mind P.M.S. HACKER: Wittgenstein on Frazer's Golden Bough

LEE C. RICE: Miñ Eternity in Spinoza

CHRISTOPH SCHULTE: Zimzum in Schelling Chenyang Li: Kripke's Two Definitions of Rigid Designation

Forthcoming:

Special Issue on ART, INTERPRETATION, AND REALITY Volume 42, January 1993

Includes papers by Menachem Brinker, G. Hermerén, John Hyman, Michael Krausz, Tomas Kulka, Jerrold Levinson, Jean François Lyotard, Joseph Margolis, J.J.A. Mooij, Stefan Morawski, Mary Mothersill, Richard Shusterman, Eddy M. Zemach

Cheques should be made payable to the Jerusalem Philosophical Society and addressed to the S.H. Bergman Center for Philosophical Studies, The Hebrew University of Jerusalem, 91905 Israel.

Annual subscription: 4 issues $\$ 20$ (postpaid $\$ 23$ ); 2 (English) issues $\$ 10$ (postpaid S12). SPECIAL ISSUE for nonsubscribers: $\$ 15$. 


\section{PHILOSOPHIQUES \\ Revue de la Société de Philosophie du Québec}

\section{SOMMAIRE}

Vol. XIX, N²

Printemps 1992

\section{Articles}

JEAN-PIERRE COMETTI, Raison, argumentation et légitimation.

Habermas, Apel et les apories de la communication ...................................3

JOSETTE LANTEIGNE, Quelques remarques sur le jugement ...........25

LEE C. RICE, La causalité adéquate chez Spinoza ................................45

JEAN-ERNEST JOOS, Banalité du mal et sens du dewoir

chez les administrateurs de l'extermination

CHRISTINE FAURÉ, Le statut du serment et de la promesse

dans la Déclaration des Droits de 1789

Intervention

JOHN O'NEAL, Le continuum corps-esprit

et l'économie de notre être selon Bonnet.

Etudes critiques

GEORGES LEROUX, Heidegger et Platon.

Le probleme du nihilisme, de Alain Boutot

ROBERT HEBERT, Savoir des juges et savoir des juristes.

Mes premiers regards sur la culture juridique québécoise, de Christian Atias

Compléments habituels: comptes rendus, livres reçus, etc.

On s'abonne à Philosophiques en devenant membre de la

Société de Philosophie du Québec

C.P. 1370, Place Bonaventure, Montréal, Québec H5A 1 H2

ou en s'adressant aux

Editions Bellarmin

165, rue Deslauriers, Saint-Laurent, Québec H4N 2 S4

Prix de l'abonnement (en dollars canadiens)

Institutions: 50 \$; individus: 30 \$; étudiants: 15 \$;

prix d'un numéro: 15 \$; abonnement de soutien: $50 \$$

Les textes pour la revue doivent être soumis à la directrice:

Josiane Boulad-Ayoub, Département de philosophie, Université du Québec à Montréal

C.P. 8888, succ. "A" Montráal H3C 3P8, Québec, Canada 


\section{PHILOSOPHIA}

Philosophical Quarterly of Israel

Editor: Asa Kasher

\section{Articles from Volume 21, 1991-1992}

Isaac Nevo: What Price Deconstruction?

Derrida on Heidegger and the Question of Nazism: A Critical Study

Fred Feldman: The Enigma of Death

Michael Wreen: Abortion and Pregnancy due to Rape

Charles Taliaferro: Imaginary Evil: A Skeptic's Wager

Sven Ove Hansson: The Paradox of the Believer

Richard I. Kirkham: On Paradoxes and A Surprise Exam

Howard Burdick: Non-Essentialistic Modal Logic

Robert Dunn: Reasons, Attitudes and the Breakdown of Reasons

Steve Edwards: Formulating a Plausible Relativism

James E. Taylor: Scepticism and the Nature of Knowledge

Series: On "Error"

4. Leslie Armour: Error and the Idealist

5. V.L. McGeer: The Problem of Error: A Surd Spot in Rational Intentionalism

6. Ehud Rahat: Metaphors and Malapropisms

7. Michael P. Levine: Berkeley: How to Make a Mistake

Next Series: On Emotions

Discussions, Critical Studies, Book Reviews

\section{Editorial addresses:}

PHILOSOPHIA, Bar-Ilan University, Ramat-Gan 52100, Israel Prof. Asa Kasher, A. Horodisch Chair of Philosophy of Language, Tel-Aviv University, Tel-Aviv 69978, Israel

ASA0425@TAUNIVM.BITNE'T or ASA0425@TAUNIVM.TAU.AC.IL 


\section{the review of}

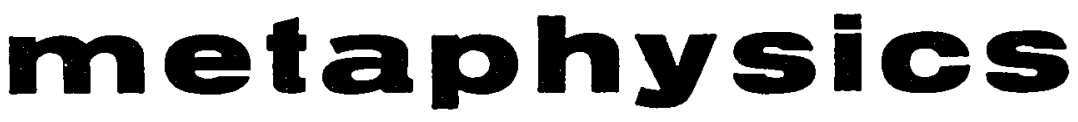

a philosophical quarterly

ISSN 0034-6632

JUNE 1992 | VOL. XLV, No.4 | ISSUE No. 180 | \$11.00

articles

books received

philosophical abstracts

announcements

RICHARD H. SCHLAGEL

JOHN MARSHALL

WILLIAM SACKSTEDER
Meeting Hume's Skeptical Challenge

Why Rational Egoism is not Consistent Three Diverse Sciences in Hobbes: First Philosophy, Geometry, and Physics

A. Z. FRIEDMAN Maimonides and Kant on Metaphysics and Piety

A. S. CUA

The Idea of Confucian Tradition

MATTHEW CUDDEBACK AND STAFF

Summaries and Comments

philosophical abstracts

announcements

index

Individual Subscriptions $\$ 25.00 \quad$ Institutional Subscriptions $\$ 42.00$

Student/Retired Subscriptions $\$ 15.00$ 




\title{
Volume Thirteen
}

SPRING 1991

R. P. Peerenboom: Beyond Naturalism: A Reconstruction of Daoist Environmental Ethics

Steven Kraft, Steven Keffer, and Sallie King: Process Philosophy and Minimalism: Implications for Public Policy

James C. Anderson: Moral Planes and Intrinsic Values

Roger J. H. King: Environmental Ethics and the Case for Hunting

SUMMER 1991

Max O. Hallman: Nietzsche's Environmental Ethics

Robin Attfield: Has the History of Philosophy Ruined the Environment?

Kelly Bulkley: The Quest for Transformational Experience

Val Plumwood: Ethics and Instrumentalism: A Response to Janna Thompson

Kareen B. Sturgeon: The Classroom as a Model of the World

Gary E. Varner: No Holism without Pluralism

FALL 1991

Kenneth Sayre: An Alternative View of Environmental Ethics

John N. Martin: Order Theoretic Properties of Holistic Ethical Theories

Bryan G. Norton: Thoreau's Insect Analogies: Or, Why Environmentalists Hate Mainstream Economist

Saroj Chawla: Linguistic and Philosophical Roots of Our Environmental Crisis

\section{WINTER 1991}

Alastair S. Gunn: The Restoration of Species and Natural Environments Jim Cheney: Callicott's "Metaphysics of Morals"

Kristin Shrader-Frechette: Ethical Dilemmas and Radioactive Waste

Steve Odin: The Japanese Concept of Nature in Relation to the Environmental Ethics and Conservation Aesthetics of Aldo Leopold

\begin{abstract}
Subscription price per volume (four issues) anywhere In the world: Individuals, $\$ 18$ (\$6 per copy); Institutions, Libraries, Private Organizations, International, Federal, State, and Local Offices and Agencies, $\$ 36$ (\$9 per copy). For air printed matter add $\$ 16$. All payments must be in U.S. Dollars and payable at a bank within the U.S. Prepayment is required at the individual rate.
\end{abstract}

Send Remittance to:

ENVIRONMENTAL ETHICS, Department of Philosophy, P. O. Box 13496

University of North Texas, Denton, TX 76203-3496

\section{ALL BACK ISSUES AVAILABLE AT CURRENT SUBSCRIPTION PRICES}

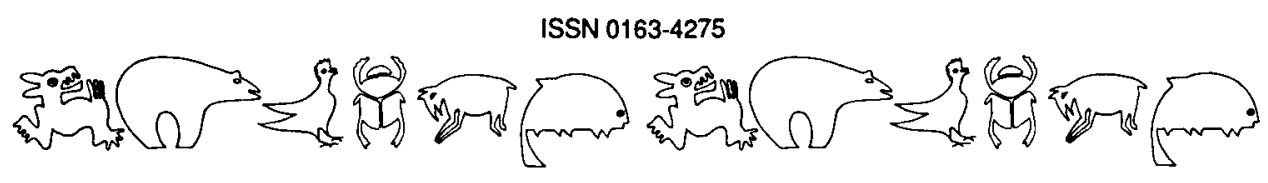




\title{
THE PHILOSOPHICAL QUARTERLY
}

\author{
Edited in the University of St Andrews \\ Chairman of the Board of Editors: NEIL COOPER \\ Executioe Editor: ROGER SQUIRES \\ Reviezos Editor: JOHN HALDANE
}

Founded in 1950, the Quarterly is one of the best established journals in the field. It aims to publish significant papers in all branches of the subject, discussions of new philosophical work, reviews of books and book notes.

Recent articles and discussions include:

- All The Difference In The World

Tim Crane

- Visual Fictions Gregory Currie

- Is There Higher-Order Vagueness? Mark Sainsbury

- Thoughts Which Only I Can Think CJF Williams

\section{Recent Reviews by}

Elizabeth Anscombe, Tom Baldwin, Edward Craig, Stephen Darwall, Michael Dummett, Antony Flew, Graeme Forbes, David Hamlyn, John Heil, Jennifer Hornsby, Anthony Kenny, Alasdair MacIntyre, Mary Midgley, Harold Noonan, Roger Scruton and Charles Travis

\section{ORDER FORM}

Subscription Rates, Volume 42, 1992 ISSN 0031-8094

Cenedien curtomen should add 7\% OST

Individuals $\mathbf{E 1 7 . 0 0}$ (UK/Europe), $\mathbf{\$ 3 6 . 5 0}$ (North America), $\mathbf{2 1 . 5 0}$ (Etsewhere)

Institutlons $\$ 46.00$ (UK/Europe), $\$ 105.00$ (North America), 862.00 (Elsewhere)

$\square \quad$ Please enter my subscription/send me a sample copy

I enclose a cheque/money order made payable to Basil Blackwell Ltd

D Please charge my Access/American Express/Mastercard/Eurocard

Card Number Expiry Date

For payments via the Natlonal Girobank, the Basil Blackwell account number is 2366053 Name

Address

Post Code

Signature Date

Payment must accompany orders

Please return this form to: Marketing Manager, Blackwell Publishers, 108 Cowley Raad, Oxford, OX41JF, UKRegistered Na. 180277.

Or to: Marketing Manager, Blackwell Publishers, Three Cambridge Center, Cambridge, MA 02142, USA 







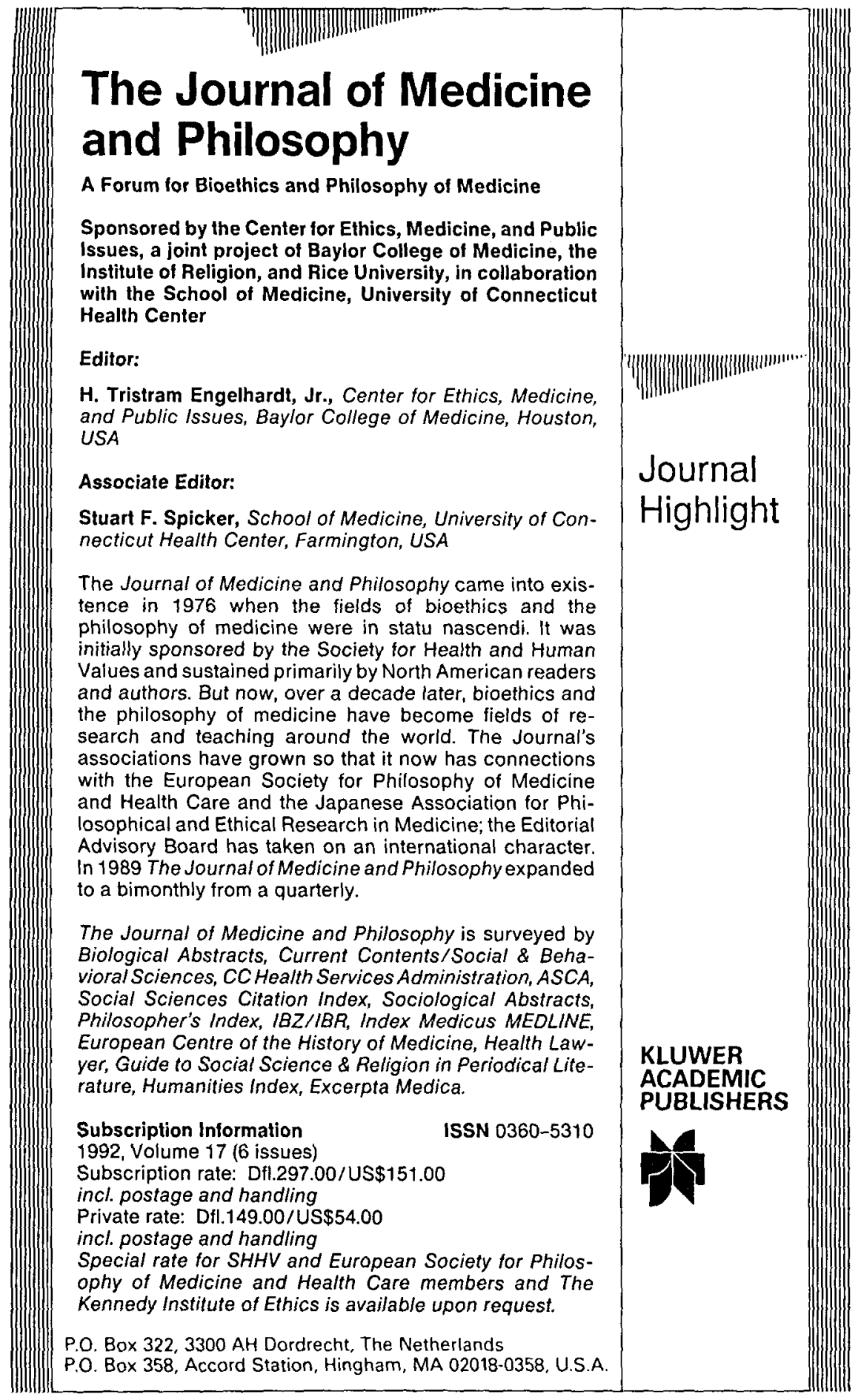




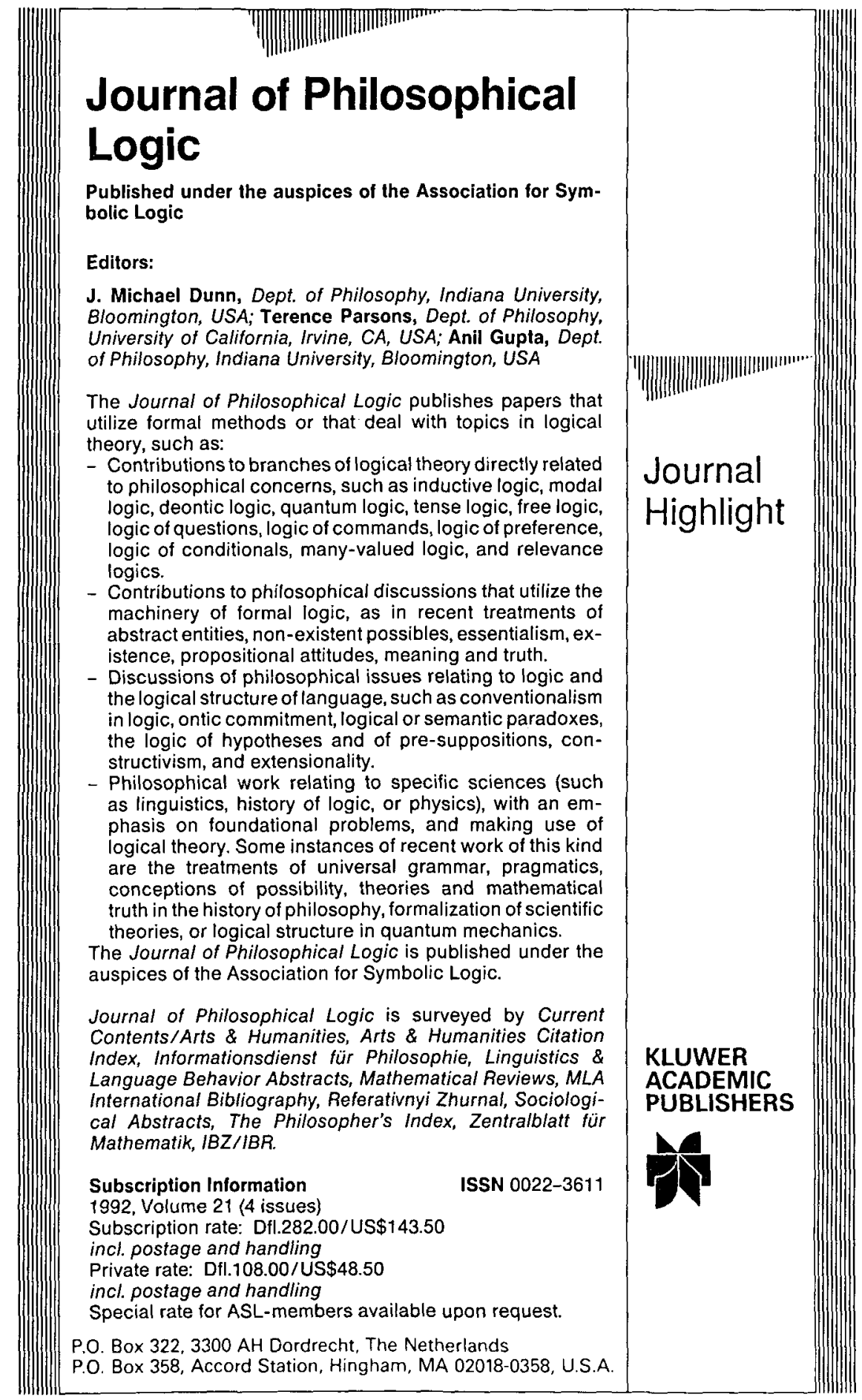




\section{PHILOSOPHIA}

Philosophical Quarterly of Israel

Editor: Asa Kasher

\section{Articles from Volume 21, 1991-1992}

Isaac Nevo: What Price Deconstruction?

Derrida on Heidegger and the Question of Nazism: A Critical Study

Fred Feldman: The Enigma of Death

Michael Wreen: Abortion and Pregnancy due to Rape

Charles Taliaferro: Imaginary Evil: A Skeptic's Wager

Sven Ove Hansson: The Paradox of the Believer

Richard I. Kirkham: On Paradoxes and A Surprise Exam

Howard Burdick: Non-Essentialistic Modal Logic

Robert Dunn: Reasons, Attitudes and the Breakdown of Reasons

Steve Edwards: Formulating a Plausible Relativism

James E. Taylor: Scepticism and the Nature of Knowledge

Series: On "Error"

4. Leslie Armour: Error and the Idealist

5. V.L. McGeer: The Problem of Error: A Surd Spot in Rational Intentionalism

6. Ehud Rahat: Metaphors and Malapropisms

7. Michael P. Levine: Berkeley: How to Make a Mistake

Next Series: On Emotions

Discussions, Critical Studies, Book Reviews

\section{Editorial addresses:}

PHILOSOPHIA, Bar-Ilan University, Ramat-Gan 52100, Israel Prof. Asa Kasher, A. Horodisch Chair of Philosophy of Language, Tel-Aviv University, Tel-Aviv 69978, Israel 


\section{POLITICAL THEORY}

An Intemational Joumal of Political Philosophy

\section{Editor: Tracy B. Strong, University of California, San Diego}

Political Theory publishes articles on political philosophy from a variety of methodological, philosophical and ideological perspectives. It offers essays in historical political thought, modern political theory, normative and analytic philosophy, the history of ideas, as well as critical assessments of current work.

The journal serves as the leading forum for the development and exchange of political ideas. It's broad in scope and international in coverage. Political Theory has no single affiliation or orientation, and it's dedicated to serving the entire political theory community.

Political Theory brings you the latest thought and theory on political philosophy. The editorial board is truly representative and international, and it's dedicated to giving you thought-provoking and informative scholarship in a variety of forms, including:

- Feature Articles

- Critical Responses

- Books in Review
- Review Essays

- Special-Topic Symposia

- Annual Index

Quarterly: February, May, August, November

\begin{tabular}{|llll|}
\hline \multicolumn{3}{|c|}{ Subscribe Today! } \\
Use the Sage FaxLine: & $1-805-499-0871$ \\
\hline & 1 Year & 2 Years & 3 Years \\
\hline Individual & $\$ 42$ & $\$ 84$ & $\$ 126$ \\
Institutional & $\$ 122$ & $\$ 244$ & $\$ 366$ \\
\hline
\end{tabular}

SAGE PUBLICATIONS, INC. 2455 Teller Road Newbury Park, CA 91320 


\section{Philosophy \& Social an international quarterly journal David M. Rasmussen, Editor} Focusing on:
$\theta$ Continental Thought
$\ominus$ American Philosophy
$\ominus$ Hermeneutics
$\theta$ Ethics
$\theta$ Literary Theory
$\Theta$ Law
$\ominus$ Cultural Critique
9 Politics
$\theta$ Modernity and Postmodernity

\section{Criticism}



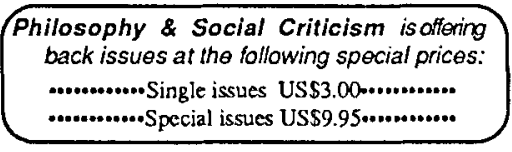

Some issues available:

Volume 16 Number 4

Ingram - Dworkin, Habermas, and the CLS Movement on Moral Criticism in Law

Cunningham Democracy and Socialism: Philosophical Aporiae

Popov-Community and Utopia: A Transcendental Deduction Miller $\cdot$ Marxist Literary Aesthetics

Volume 16 Number 3

Corradi*Metaphoric Structure of Sociological Explanation Barbie ro - The Roots of Ferry and Renaut's llumanism Rockmore -Marx and Perestroika

Hoy -Contra Deconstructivism

Moss-Ethical Expertise and Moral Maturity

Volume 16 Number 2

Ferrara -The Unbearable Seriousness of Irony Bergoffen. The Body Politic

Bulog $\cdot$ Max Horkheimer's Social Theory and Critique Honneth On the Anthropology of Claude Lévi-Strauss Matustik •(editorial correction) Jirgen Habermas at 60

Volume 16 Number 1

Haylm.Hegel's Critical theory and Frcminist Concems Geiman-Lyoiard's "kanuan Socialism"

Phelan -Adorno and Feminist Essentialism

Howard *A Response to Petrey

Matustlk-Jürgen Habermas at 60

Back Issues
Single Issues $\$ 3.00$ US
Special Issues $\$ 9.95$ US
full list available upon request

Name

\section{Mailing address}

Volume 15 Number 4

D'Entrèves -Freedom, Plurality, Solidarity: Arendt's Theory of Action

Pensky-Habermas, "Anamnestic Solidarity", and the Historikerstreit

Bohman.Habermas and the Problem of Holism

Koman-Thinking Politics without a Philosophy of History: Arendt and Merleau-Ponty

Volume 15 Number 3 Special Issue on Acsthetics

IIcller-Unknown Masterpiece

Korthals*Critical Theory about the Conflict and Harmony between Art and Morality

Negrin-The End of Aesthetic Theory

Ilanrahan $\cdot$ Negative Composition

Petrey-Iterating Revolution: Speech Acts in Literacy Theory

Volume 15 Number 2

Ke mp.Heidegger's Greatness and His Blindness

Arnason-The Hermeneutical Undercurrent in Critical Theory

Fisk-Intellectuals, Values and Society

May.Is Post-Structuralist Political Theory Anarchist?

Barash - The Use and Abuse of Legal Theory: A Reply to Fish

Rorty•A Post-Philosophical Politics? An Interview by Danny Postel

Volume 15 Number 1

Lawlor-From the Trace to the Law: Derridean Politics Pawtzold $\cdot$ Marxism and Philosophical Anthropology

Fricd The Centrality of International Law and International Organizations for J'eace in the Nuclear Age

Niclse n-Liberal and Socialist Egalitarianism

Iloward -Critical Theory and The Closing of the American Mind

Current Subscription Rates: Volume 18 (1992)

Library \$80 US \& Canada/\$88 Foreign

Individual \$30 US \& Canada/\$33 Foreign

Full time Student $\$ 25$ US \& Canada / $\$ 28$ Foreign

SEND CHECK PAYABLE TO: PHILOSOPHY AND SOCIAL CRITICISM 


\title{
AUSTRALASIAN JOURNAL OF PHILOSOPHY
}

\author{
Editor: Robert Young
}

\section{SOME RECENT AND FORTHCOMING ARTICLES}

Julia Driver

John Martin Fischer and Mark Ravizza

The Suberogatory

The Inevitable

Daniel Gilman

EJ. Lowe

Peter Milne

Kim Sterelny

Timothy Williamson

A New Perspective on Pictorial Representation The Problem of Psychophysical Causation Modal Metaphysics and Comparatives Evolutionary Explanations of Human Behaviour

Verificationism and Non-Distributive Knowledge

Annual Subscription: Individuals A\$35 (US\$35 or Stg17.50); Institutions $\mathbf{A} \$ 60$ (US\$60 or Stgf30). All correspondence should be addressed either to the Editor or to the Business Manager, Australasian Journal of Philosophy, Department of Philosophy, La Trobe University, Bundoora, Victoria, 3083, Australia.

Published quarterly by

The Australasian Association of Philosophy

\section{THE CLASSICAL WORLD}

Published six times yearly (from September to July). Each volume contains approximately 450 pages. Paid international circulation of more than 3,000.

Since $1907 \mathrm{CW}$ has provided a combination of services and features which make the journal an indispensable tool for teaching and research in the Classics.

ARTICLES ...

of scholarly and general interest to students of Graeco-Roman culture and its aftermath.

SURVEYS...

complete and annotated bibliographical surveys of scholarship on authors, genres, special areas.

REVIEWS. . .

$C W$ specializes in the brief and expert review of new books in all areas of Classical Antiquity and related subjects.

BOOKS RECEIVED ...

extensive and immediate listing of all books received from publishers around the world with complete bibliographical information.

For a free sample copy of $\mathrm{CW}$ and subscription blank write to

\author{
The Classical World \\ Department of Classics \\ Duquesne University \\ Pittsburgh, PA 15282
}


Acknowledgements/

Remerciements
The Canadian Journal of Philosophy is published with the aid of a grant from the Social Sciences and Humanities Research Council of Canada.

La publication du The Canadian Journal of Philosophy est rendue possible grâceà une subvention du Conseil de Recherches Humaines du Canada.

The Canadian Journal of Philosophy wishes to thank the University of Lethbridge for its generous support for the editorial administration of the journal.

The Canadian Journal of Philosophy tient à remercier l'Université de Lethbridge de l'aide généreuse qu'elle apporte à la gestion de sa rédaction.

The Canadian Journal of Philosophy is grateful for past support from its originating sponsor, the Canadian Association for Publishing in Philosophy. The Association is a non-profit organization, incorporated under the laws of Canada, with the object of promoting and publishing learned publications in philosophy. A regular member of the Association is a member of, and appointed by, any department of philosophy in a Canadian university, upon payment of a subscription by that department. The Association is a Registered Canadian Charitable Organization within the meaning of the Income Tax Act; donations to the Association are thus tax deductible.

The Canadian Journal of Philosophy désire exprimer sa gratitude à l'Association Canadienne des Publications en Philosophie qui l'a aidé par le passé. L'Association est un organisme à but non lucratif, incorporé aux termes de la loi canadienne, ayant pour objet la promotion et la publication d'études savantes en philosophie. Tout membre appartenant à, et désigné par, un département de philosophie d'une université canadienne est de facto, au reçu du règlement de l'abonnement départemental, membre à part entière de l'Association. L'Association est inscrite au Registre officiel des Organismes de Charité canadiens aux termes de la loi de l'impôt sur le revenu; les donations dont elle fait l'objet peuvent bénéficier ainsi du dégrèvement d'impôt. 